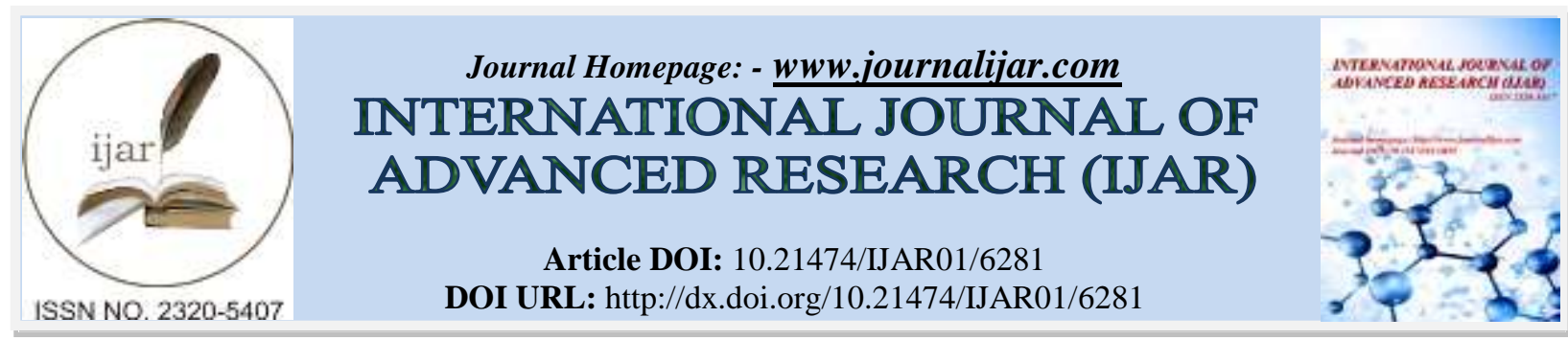

RESEARCH ARTICLE

\title{
RELATIONSHIP BETWEEN CADMIUM ACCUMULATION AND SOIL EC (A CASE STUDY OF FIVE AUTOMOBILE WORKSHOPS).
}

\author{
Okeke C. U. ${ }^{1}$, Ekanem. E. O. ${ }^{2}$, Adamu. H. M. ${ }^{2}$ and Kolo. A. M. ${ }^{2}$ \\ 1. College of Education, Kangere Bauchi Bauchi state, Nigeria. \\ 2. Department of Chemistry, Facaulty of Science, Abubakar Tafawa Balewa University, Bauchi state, Nigeria.
}

\section{Manuscript Info}

Manuscript History

Received: 11 November 2017

Final Accepted: 13 December 2017

Published: January 2018

Keywords:-

Cadmium, Soil conductivity, Coefficient

of correlation, Regression models.

\section{Abstract}

This study was conducted with soils samples from five mechanic workshops within Bauchi metropolis with a view to examine the relationship between $\mathrm{Cd}$ and the electrical conductivity in these soils. Resulting coefficient of correlation established a linear relationship between the both variables, with $\mathrm{R}^{2}$ of between $0.869-0.955$ in all the study sites. Three different models (Linear, Logarithmic and quadratic models) were developed were found to suit the data obtained from the correlation between $\mathrm{Cd}$ and soil EC. Regression models obtained can be used to predict the impact of $\mathrm{Cd}$ in the various workshops.

Copy Right, IJAR, 2018,. All rights reserved.

\section{Introduction:-}

The ongoing rapid economic boost through industrialization and urbanization has put a great burden on soil, with more and more pollutants containing heavy metals being released into the soil on daily basis (Banat et al., 2004; Yang et al., 2011; Nor et al., 2012). The annually estimated toxicity due to metallic discharge into the environments far exceeds the combined total toxicity of all radioactive and organic wastes (Abdus-Salam and Adekola, 2005).The accumulation of heavy metals in the environment particularly in the soil due to their persistent nature is now a matter of continuous growing environmental and health concerns all over the world (Abdus-Salam and Adekola, 2005; Parven et al., 2009; Abechi et al., 2010; Adams et al., 2015). In Nigeria, soils suffer from pollution problems associated with automobile-repair workshop (Onweremadu and Duruigbo, 2007; Ayodele and Modupe, 2008; Nwachukwu et al., 2010; Odoh et al., 2011; Ojiako and Okonkwo, 2013; Okeke et al., 2014; Osakwe, 2014; Iyabo et al., 2015).

Cadmium has been reported as one of the major metals pollutant associated with all automobile workshops within Africa (Iwegbue et al., 2006; Ilemobayo and Kolade, 2008; Adelekan and Alawode, 2011; Ololade, 2014; Demie, 2015). Large concentrations of $\mathrm{Cd}$ in soils are associated with parent material (black slates) and most are manmade (Victor, 2009) ${ }^{1}$. Cadmium pollution of the environment has been on the increase due to rising consumption of Cd by industries. Cadmium is contained in motor oils and car tyres; it is principally used as protective plating on steel, in cadmium- nickel battery manufacture, in various alloys, in paints and pigment (for plastic, enamels and glasses); industrially, it is used as air antifriction agent, as rust proofer and in alloys in semiconductors (Duffus, 1980, Alloway, 1999, Kadirvelu and Namasivayam, 2003; Ihenyen and Aghimen, 2005; Arinola and Akinbinu, 2006; Lenntech, 2011). Its sources in the environment could also be attributed to the use of commercial fertilizers, containing cadmium, insecticides, fungicides and sludge used in agriculture (Omran and El Razek, 2012). 
Cd is very toxic at very low concentration and is considered as one of the most important environmental pollutants due to its potential harmful effects and no known biological importance or essential function to date. It has therefore received as much attention as those of lead Onweremadu and Duruigbo, 2007; Alloway, 1996; Omran and El Razek, 2012; Lehoczky et al, 2000). Cadmium toxicity is linked with reproduction problem because it affects sperm and reduces birth weight (Victor, 2009). It is a potential carcinogen and seems to be a causal factor in cardiovascular diseases and hypertension. It's inhalation can lead to severe damage of the lungs and even death. High level of cadmium in exposed individuals may interfere with cerebral pyruvate metabolism, which may lead to thiamine deficiency, emphysema and proteinuria in the occupationally exposed individuals (Arinola and Akinbinu, 2006; Lenntech, 2011). People living close to waste dump, where cadmium accumulates can be at a high risk of exposure (Lenntech, 2011).

This will likely be the case for those living near automobile dumpsites and workshops. Nawrot et al, 2006 reported that a significant increase in lung cancer risk correlated with cadmium exposure in soil, around former thermal zinc plants.

Within the soil profile, $\mathrm{Cd}$ tends to be present at higher concentration in the surface horizon. This partly reflects the inputs from direct discharge of automobile wastes on soil and atmospheric deposition. It also tends to be more mobile in soil at lower $\mathrm{pH}$ than other metals such as $\mathrm{Cu}$ and $\mathrm{Pb}$ (Alloway, 1996; Alkorta $\mathrm{J}$ et al., 2004; Haiyan, 2013). The estimated half - life for $\mathrm{Cd}$ in soil varies between 15 - 1100 years. This is an obviously long term problem and its pollution needs to be prevented or monitor, wherever possible (Alloway, 1996).

Electrical conductivity (EC) is the ability of a material to transmit (conduct) an electrical current. Soil electrical conductivity offers a very quick and convenient way for determining the total amount of ionisable salt. These substances are the ions, which act as a good conductor. The existence of some ions in the soil changes soil electrical conductivity value. The nature of various substances, their concentration and ionic strengths vitally affect the conductance (Seifi et al., 2010; Saroj, 2014). Salinity levels, cation exchange capacity and herbicide usage have been identified as major factors that affect the EC measurements in soils (Jaynes, et al., 1995; Mankin and Karthikeyan, 2002; Triantafilis et al., 2002; Kaffka, et al., 2005). Soil EC is therefore one of the soil physical properties, which have a good relationship with the other soil characteristics and the measurement of apparent soil electrical conductivity, is one of the easiest ways to get suitable information about soil characteristics. Soil EC is also viewed as the best way for obtaining useful information about soil pollution condition (Seifi et al., 2014).

This present study investigates the relationship between cadmium and the electrical conductivity of contaminated soil with a view to evaluate the possibility of predicting the levels of $\mathrm{Cd}$ in these soils by using the soil EC.

\section{Materials and Method:-}

\section{Study area:-}

The study was carried out in five automobile repair and maintenance sites within Bauchi metropolis, Bauchi local government area of Bauchi state. Geographically, Bauchi state lies between latitudes $9^{0} 30^{\prime} \mathrm{N}$ and $12^{0} 34^{\prime} \mathrm{N}$ and longitude $8^{0} 5^{\prime} \mathrm{E}$ and $11^{0} 00^{\prime} \mathrm{E}$ of the greenwichmeridian. Geographical coordinates of the various sites were obtained using a global positioning system.

\section{Sampling and Sample Collection:-}

Stratified random sampling technique was used. Each of the study sites were divided into ten units. Soil samples were then randomly collected at a depth of $30 \mathrm{~cm}$ in the respective units within each mechanic workshops. The soil samples per unit were then homogenised to form a composite sample (Atulegwu et al., 2013). The homogenised samples were then transferred into a black polythene bag and properly labelled before transporting to the laboratory.

\section{Sample preparation and preservation:-}

After series of coning and quartering, 500g of the soil sample from each of the sites were air dried for one week in a well-ventilated space to remove excess moisture and sieved through $2 \mathrm{~mm}$ mesh to prevent chemical microbial changes and to remove large mineral inclusions and organic debris. The sieved samples were stored in labelled polythene bags and used for subsequent analysis (Okeke et al. 2014). 


\section{Metal Determination:-}

The dried soil samples were crushed in a porcelain mortar with a pestle. $1.0 \mathrm{~g}$ of the sample were then digested with $20 \mathrm{~cm}^{3}$ aqua regia $\left(\left(\mathrm{HNO}_{3}: \mathrm{HCl}, 3: 1\right.\right.$ ratio) in a $100 \mathrm{~cm}^{3}$ cornical flask and was allowed to stand overnight. The next day the mixture was boiled gently for 2 hours at $95^{\circ} \mathrm{C}$ and allowed to cool. After rinsing the flask with $20 \mathrm{~cm}^{3} \mathrm{of}$ distilled water; the mixture was filtered through Whatman No 1 filter. The filter was also rinsed, but with $10 \mathrm{~cm}^{3}$ of warm $\left(50^{\circ} \mathrm{C}\right) \mathrm{HNO}_{3}$ and the filtrate was diluted to $100 \mathrm{~cm}^{3}$ with $2 \mathrm{M} \mathrm{HNO}_{3}$ in a $100 \mathrm{~cm}^{3}$ standard volumetric flask. The digested samples were then analyzed for their heavy metal content using the atomic absorption spectrophotometer (Bulk Scientifc 210, VGD) (Nor et al., 2012; Iwegbue et al., 2006).

\section{Electrical conductivity determination:-}

Electrical conductivity of the soil (ratio 1:5 of soil to water suspension) were measured with an EC /TDS meter (WAG-WE 30210) calibrated to a $1413 \mu \mathrm{Scm}^{-1}$ calibration standard at $25^{\circ} \mathrm{C} .5 \mathrm{~g}$ of soil was transferred in a beaker, followed with $50 \mathrm{ml}$ of distilled water. The mixture was thoroughly shaken for 1hour to dissolve the salt. The mixture was filtered through No.1 filter paper and the EC of the extract were measured at $25^{\circ} \mathrm{C}$ (Motsara and Roy, 2008).

\section{Data Analysis:-}

Data generated were analysed using SPSS 16 and statistical variations were considered significant at $\mathrm{p}<0.05$. The linear regression equation was used for the estimation and prediction of metal concentrations at the various automobile workshops. The equation was obtained from plotting a linear, Logarithmic, quadratic or cubic curve of the metal concentration against the EC of the soil at the study sites. Thus, from the equations obtained, the concentrations of $\mathrm{Cd}$ in any of the study sites can easily be deduced from the equation by substituting the values of soil EC obtained at any of the sites.

\section{Results and Discussion:-}

\section{Relationship between Soil EC and Cd Concentration in Soil:-}

Table 1 gives the summary results of the correlation between $\mathrm{Cd}$ levels and EC in automobile workshops studied. In all the workshops, EC correlated significantly and positively with $\mathrm{Cd}$ at $\mathrm{p}<0.01(\mathrm{MR}, \mathrm{r}=0.802 ; \mathrm{MW}, \mathrm{r}=0.924$; YW, $r=0.929 ;$ GR, $r=0.955$; DP; $r=0.910$ ). This could imply that an increase in the level of Cd may lead to an elevated level of soil EC in these sites.

Table 1:- Correlation analysis of Cd levels and Ec in mechanic workshop soils

\begin{tabular}{|l|l|l|l|l|l|}
\hline Sites & MR & YW & MW & GR & DP \\
\hline R & $.869^{* *}$ & $.924^{* *}$ & $.929^{* *}$ & $.955^{* *}$ & $.910^{* *}$ \\
\hline P & .001 & .000 & .000 & .000 & .000 \\
\hline
\end{tabular}

DP= Dass park; YW= Yelwa; MW= Maidugari bye-pass; GR= Gombe road; MR= Maidugari road, R:

Pearson correlation, P: Significant level, **. Correlation is significant at the 0.01 level

\section{Regression models:-}

In order to further understand the relationship between changes in the EC as the Cd level varies in the soil, series of regression analyses for the two variables were carried out to test their suitability to the data generated (Figures 1 $5)$.

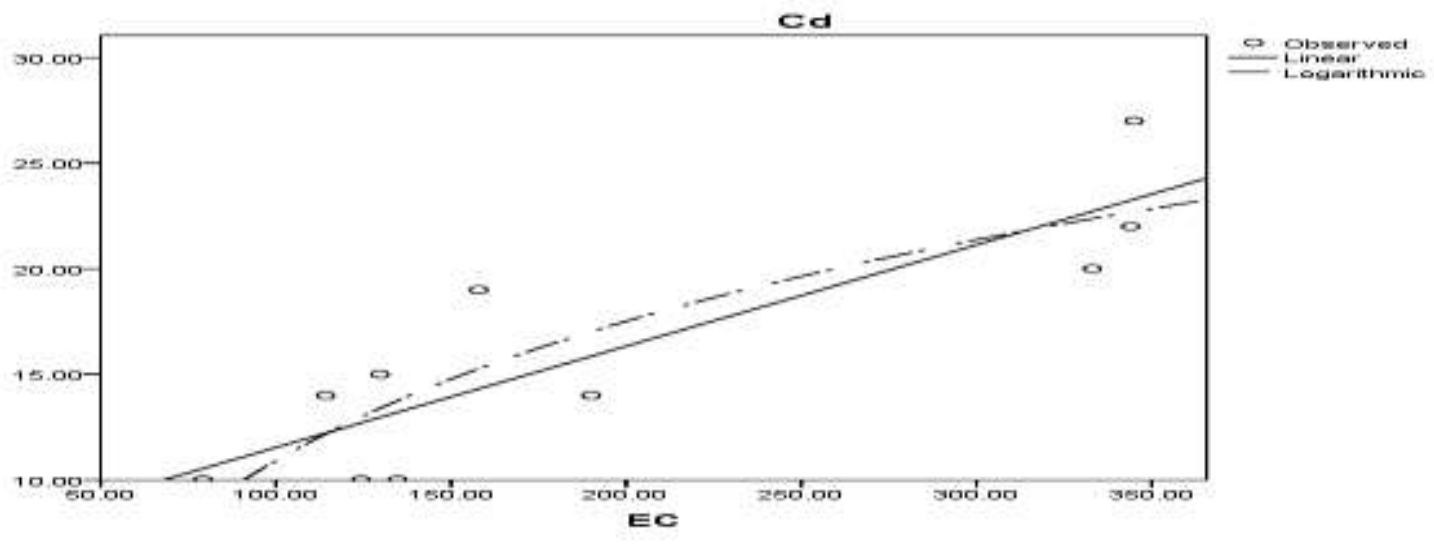


Figure 1:- Relationships between Cd and EC in MR.

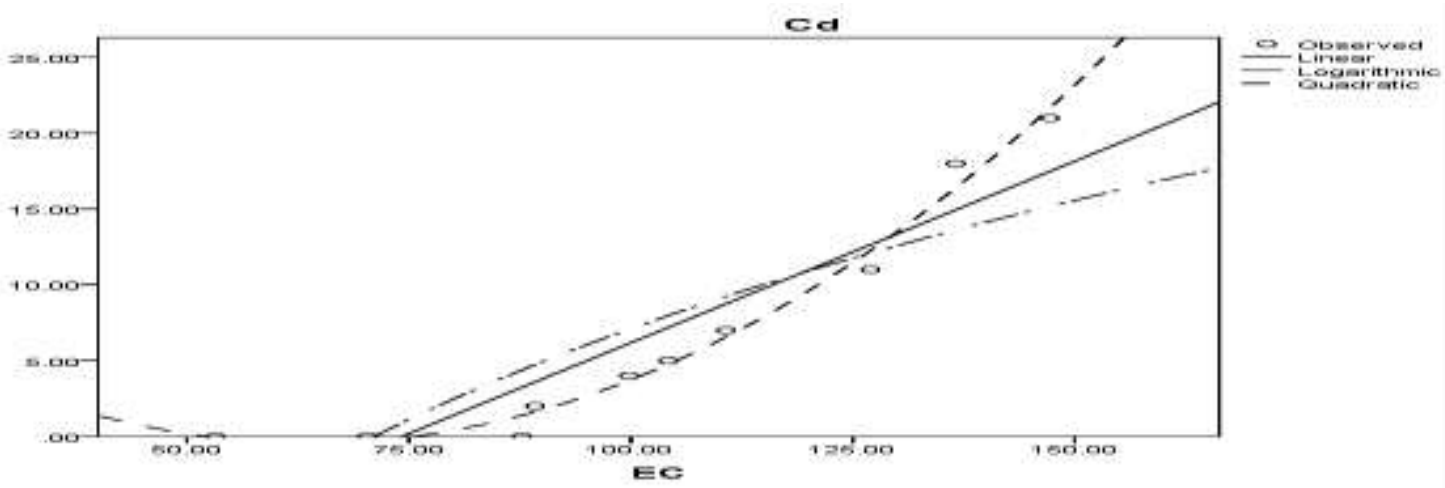

Figure 2:- Relationships between $\mathrm{Cd}$ and $\mathrm{EC}$ in MW

Plots of $\mathrm{Cd}$ against EC obtained above for the various workshops show that the levels of $\mathrm{Cd}$ in all the soil samples studied had similar increasing relationships with the corresponding EC values estimated. This interesting phenomenon indicates that the higher the Cd concentrations in soils, the higher soil EC. Linear $(Y=a+b X)$ and $\operatorname{logarithmic}(\mathrm{Y}=\mathrm{a}+\mathrm{b} \ln (\mathrm{X})$ models were generated for MR, YW and DP, while in addition to these models, the quadratic $\left(Y=a+b X+c X^{2}\right)$ models were also found suitable in MW and GR. These models were considered statistically significant at $\mathrm{P}<0.05$ for this investigation and were developed based on regression analysis in which the relationship between a dependent variable and one or more independent variable is estimated.

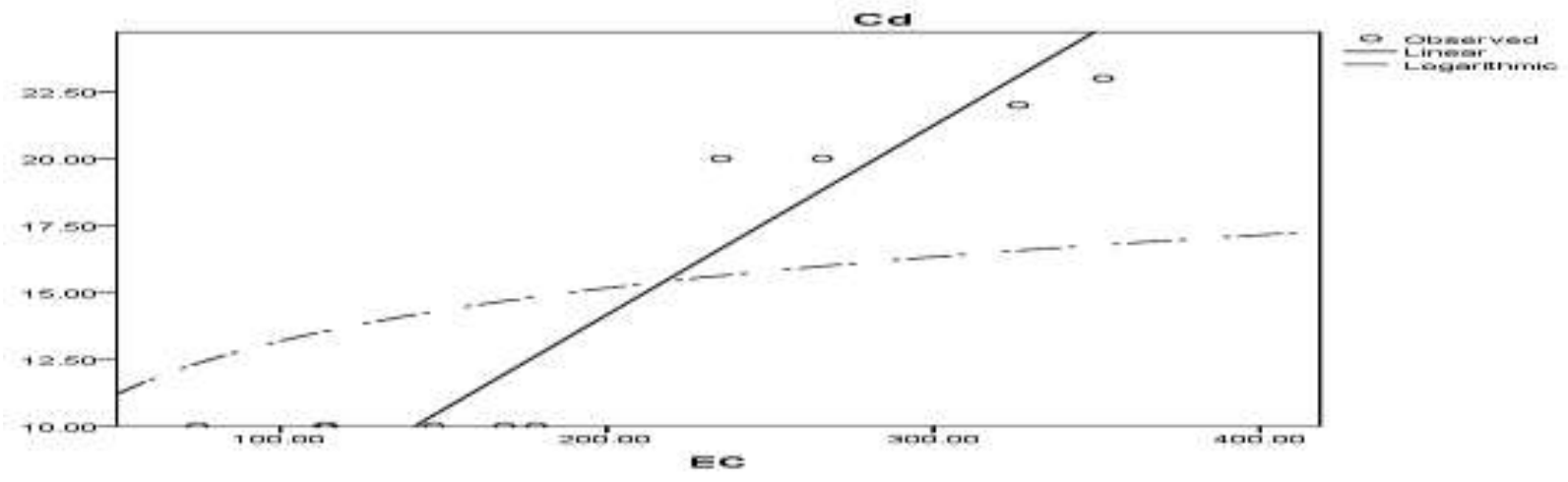

Figure 3:- Relationships between Cd and EC in YW $*_{-} / *_{-} *_{-}$

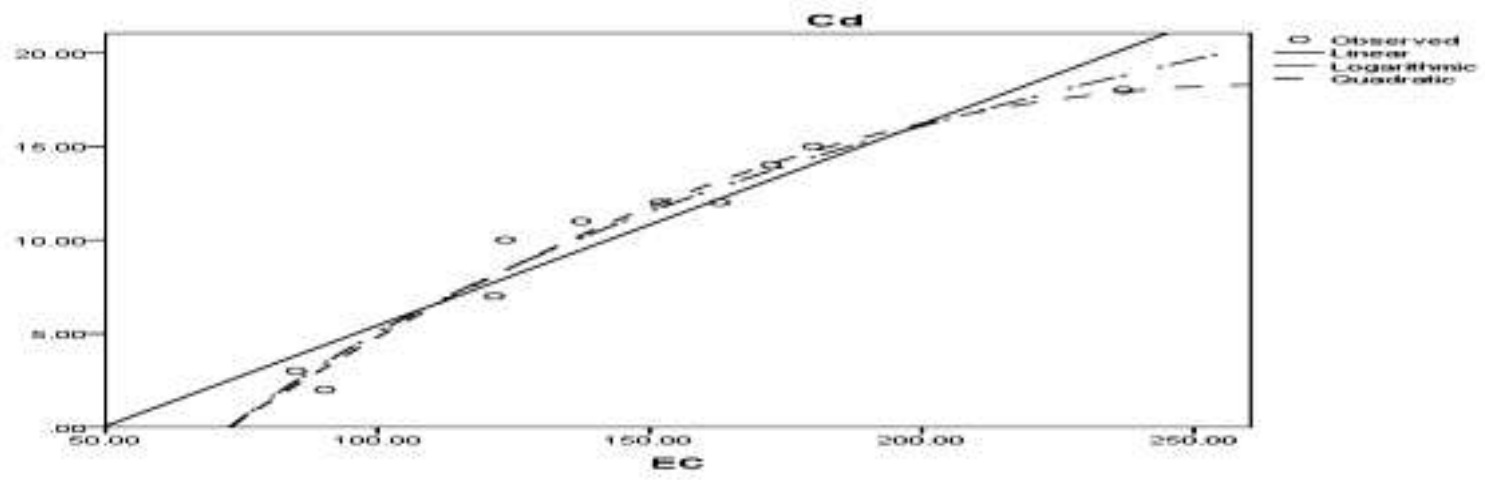

Figure 4:- Relationships between $\mathrm{Cd}$ and $\mathrm{EC}$ in GR 


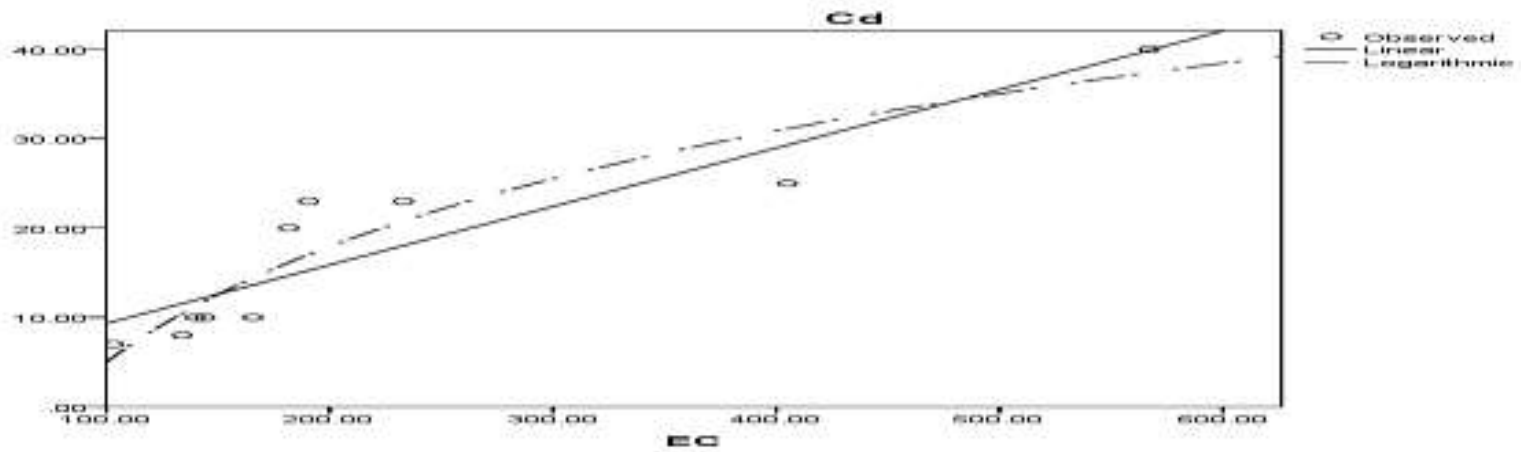

Figure 5:- Relationships between $\mathrm{Cd}$ and $\mathrm{EC}$ in $\mathrm{YW}$

Using the regression analysis therefore, it is easy to understand how the typical value of the dependent variable changes when any one of the independent variables is varied (Mogull, 2004; Amstrong, 2012). In this study, EC is the independent variable owing to its usefulness in measuring increase in the concentration and pollution of heavy metals in soils (Seifi, 2010). Soil EC can therefore be used to predict the concentrations of Cd, which is the dependent variable.

The Linear, logarithmic and quadratic regression models developed, fitted the relationships with Adjusted $\mathrm{R}^{2}$ ranging between $0.694-0.982$ (Table 2). Although all the models developed were good as shown by their $\mathrm{R}^{2}$ values, the linear models gave the highest prediction of $\mathrm{Cd}$ in $\mathrm{MR}$ and $\mathrm{YW}$, accounting for $72.4 \%$ and $84.5 \%$ of the variance in the concentration of Cd respectively, followed by the logarithmic model in GR and DP; explaining about $96.0 \%$ and $85.0 \%$ respectively. In MW, the quadratic model gave the most preferred prediction, with about $98.2 \%$.

Table 2:- Model summary of Cd in the workshop soils

\begin{tabular}{|l|c|c|c|c|c|r|}
\hline Metals & Model Type & $\mathrm{R}$ & $\mathrm{R}$ Square & $\begin{array}{c}\text { Adjusted R } \\
\text { Square }\end{array}$ & $\begin{array}{c}\text { Std. Error of the } \\
\text { Estimate }\end{array}$ & $\mathrm{F}$ \\
\hline MR & Linear & 0.869 & 0.755 & 0.724 & 3.02575 & 24.648 \\
\hline & Logarithmic & 0.859 & 0.738 & 0.706 & 3.127 & 22.570 \\
\hline MW & Linear & 0.924 & 0.853 & 0.835 & 3.081 & 46.544 \\
\hline & Logarithmic & 0.853 & 0.728 & 0.694 & 4.196 & 21.405 \\
\hline & Quadratic & 0.993 & 0.986 & 0.982 & 1.005 & 252.517 \\
\hline YW & Linear & 0.929 & 0.862 & 0.845 & 2.311 & 50.126 \\
\hline & Logarithmic & 0.871 & 0.759 & 0.729 & 3.060 & 25.167 \\
\hline GR & Linear & 0.955 & 0.911 & 0.900 & 1.610 & 82.395 \\
\hline & Logarithmic & 0.981 & 0.963 & 0.958 & 1.047 & 205.638 \\
\hline & Quadratic & 0.983 & 0.967 & 0.957 & 1.052 & 102.360 \\
\hline DP & Linear & 0.910 & 0.828 & 0.806 & 4.639 & 38.387 \\
\hline & Logarithmic & 0.932 & 0.868 & 0.851 & 4.060 & 52.573 \\
\hline
\end{tabular}

DP= Dass park; MV= Mechanic village; $\mathrm{YW}=$ Yelwa; $\mathrm{MW}=$ Maidugari bye-pass; $\mathbf{G R}=$ Gombe road; $\mathrm{MR}=$ Maidugari road,

Table 3:- Regression models developed for $\mathrm{Cd}$

\begin{tabular}{|l|c|c|c|}
\hline Metals & Linear models & Logarithmic models & Quadratic models \\
\hline MR & $\mathrm{Cd}=6.73+0.050 \mathrm{EC}$ & $\mathrm{Cd}=9.525 \ln (\mathrm{EC})-32.95$ & -- \\
\hline MW & $\mathrm{Cd}=-17.77+0.239 \mathrm{EC}$ & $\mathrm{Cd}=20.854 \ln (\mathrm{EC})-88.92$ & $\mathrm{Cd}=12.54-0.406 \mathrm{EC}+0.003 \mathrm{EC}^{2}$ \\
\hline YW & $\mathrm{Cd}=3.021+0.058 \mathrm{EC}$ & $\mathrm{Cd}=10.200 \ln (\mathrm{EC})-38.32$ & -- \\
\hline GR & $\mathrm{Cd}=-5.329+0.108 \mathrm{EC}$ & $\mathrm{Cd}=15.920 \ln (\mathrm{EC})-68.25$ & $\mathrm{Cd}=-16.55+0.263 \mathrm{EC}+0.000 \mathrm{EC}^{2}$ \\
\hline DP & $\mathrm{Cd}=2.782+0.065 \mathrm{EC}$ & $\mathrm{Cd}=18.676 \ln (\mathrm{EC})+81.01$ & -- \\
\hline
\end{tabular}

It accounted for approximately $98.0 \%$ of the variation in Cd concentration. This is because these preferred models gave higher $\mathrm{R}^{2}$ values, lower standard errors of the estimate and enormous $\mathrm{F}$ statistics (Table 3 ). 


\section{Conclusion:-}

This study revealed that $\mathrm{Cd}$ concentrations generally increased as the soil EC increased in all the automobile workshops studied. In other words, the concentrations of $\mathrm{Cd}$ in soils can be easily related to the measured EC of such soils and these relationships can be expressed mathematically with regression equations. The study also indicated that the model equations can be utilized for predicting the level of $\mathrm{Cd}$ at any of the study sites by simply imputing the value of the measured soil EC values in any of these study sites. Mathematical models so obtained can be used in the prevention Cd pollution in automobile workshops, giving a first indication about the elevated level of $\mathrm{Cd}$ in the workshops.

\section{Reference:-}

1. Abechi, E. S., Okunola, O. J., Zubairu, S. M. J., Usman, A. A., Apene, A. (2010) Evaluation of Heavy metals in roadside soils of major streets in Jos Metropolis, Nigeria. Journal of Environmental chemistry and Ecotoxicology, 2(6): $98-102$.

2. Abdus-Salam, N. and Adekola, F. A. (2005) The Influence of pH and Adsorbent Concentration on Adsorption of Lead and Zinc on a Natural Goethite. African Journal of Science and Technology (AJST) Science and Engineering Series, 6 (2): 55 - 66.

3. Adams, S., Richard, A., Samuel, J. A., Kwabena, A. N., Eric, A., Eric, O. A. (2015) Assessment of Heavy Metal Contamination In Soils Around Auto Mechanic Workshop Clusters In Central Agricultural Station, Kumasi-Ghana. Applied Research Journal, 2015, 2: 12 - 19.

4. Adelekan, B. A and Alawode, A. O. (2011) Concentrations of Muncipal refuse dumps to heavy metals concentrations in soil profile and ground water Ibadan. Nigeria. J. Appl. Biosci., 40:2727-2737.

5. Alkorta, J. H., Becerril, J. M., Amezaga, I., Albizu, I., and Garbisu, C. (2004) Recent findings on the phytoremediation of soils contaminated with environmentally toxic heavy metals and metalloids such as zinc, cadmium, lead, and arsenic. Reviews in Environmental Science and Bio/Technology, 3: 71-90,

6. Arinola, O. G. and Akinbinu, M. O. (2006) The levels of antioxidants and some trace metals in Nigerians that are occupationally exposed to chemicals. India journal of occupational and environment medicine, 10 (2): 65 68.

7. Armstrong, J. S. (2012) Illusion in Regression Analysis. International Journal of Forecasting, 28 (3): 689

8. Atulegwu. P. U., Luke, U., Erick, O., Clifford, O. K. and Austine, O. (2013) Modelling Lateral Distribution of Heavy Metal and Bio-accumulation in Earthworm in the Varying Acidic Surface Horizon of Waste- Polluted Soil. International Journal of Energy Engineering, 3(2): 45-54.

9. Ayodele, R. I. and Modupe, D. (2008) Heavy metals contamination of topsoil and dispersion in the vicinities of reclaimed auto-repair workshops in Iwo, Nigeria. Bull.Chem. Soc. Ethiop., 22(3): 339-348.

10. Banat, K. M., Hawari, F. M. and Al Hamad, A. A. (2004) Heavy metals in urban soils of central Jordan: should we worry about their environmental risks? Environ. Res., 97(3):258-273.

11. Alloway, B. J. (1996) Cadmium. In: Heavy metals in soils, B. J. Alloway (Eds.), New York, NY: John Wiley and sons, Inc, pg. 100.

12. Demie, G. (2015) Analyzing soil contamination status in garage and auto mechanical workshops of Shashemane City: implication for hazardous waste management. Arabian Journal for Science and Engineering, 31(2A): 147158.

13. Duffus J. H. (1980), Environmental Toxicology (Resource and environmental science. Edward Arnold (Publishers) Ltd., London, pp 68-78.

14. Haiyan. L., Anbang, S., Mingyi, L. and Xiaoran Z. (2013) Effect of pH, temperature, dissolved oxygen and flow rate of overlying water on heavy metals released from storm sewer sediments. Journal of chemistry, 2013: $1-$ 11.

15. Ihenyen, A. E. and Aghimen, A. E. (2005) A study of trace heavy metal levels in Warri soils and vegetables, Southern Nigeria. Ecoserve Publishers, 1 (1): 9.

16. Ilemobayo, O. and Kolad, I. (2008) Profile of heavy metals from automobile workshops in Akure, Nigeria. J. Environ. Sci. Technol., 1: 19-26

17. Iwegbue, C. M. A., Isirimah, N. O., Igwe, C. and Williams, E. S. (2006) Characteristic levels of heavy metals in soil profiles of automobile mechanic waste dumps in Nigeria. Environmentalist, 26: 123 -128.

18. Iyabo, O. O., James, O. O. and Osibanjo, O. (2015) Analysis of Heavy Metals and Some Physicochemical Parameters in Soil of Major Industrial Dumpsites in Akure Township, Ondo State of South Western Nigeria. International Journal of Chemistry, 7(1): 55-61. 
19. Jaynes, D. B., Novak. J. M., Moorman, T. B. and Cambardella, C. A. (1995) Estimating herbicide partition coeficients from electromagnetic induction measurements. J. Environ. Qual., 24: 36-41.

20. Kadirvelu, K. and Namasivayam, C. (2003) Activated Carbon from cocnut coirpith as metal adsorbent of Cd from aqueous solution. Advance in Environmental Research, 2003, 7: 471 - 478.

21. Kaffka, S. R., Lesch, S. M., Bali, K. M. and Corwin, D. L. (2005) Site-specific management in salt-affected sugar beat fields using electromagnetic induction. Comput. Electron. Agric.,46: 329-350.

22. Lehoczky, E, Marth, P., Szabados, I., Palkovics, M. and Luka' cs, P. (2000) Influence of soil factors on the accumulation of cadmium by lettuce. Commun. Soil Sci. Plant Anal., 31: 2425- 2431

23. Lenntech (2011) Cadmium (Cd) - Chemical properties, health and environmental effects. htt://www.lenntech.com/periodic/elements/cd.htm

24. Mankin, K. R. and Karthikeyan, R. (2002) Field assessment of saline seep remediation using electromagnetic induction. Trans. ASAE., 45(1): 99-107.

25. Mogull, R. G. (2004) Second-Semester Applied Statistics. Kendall/Hunt Publishing Company, pp.59.

26. Motsara, M. R. and Roy, R. N. (2008). Guide to laboratory establishment for plant nutrient analysis.Foodand Agriculture Organisation of the United Nations (FAO) Fertilizer And Plant Nutrition Bulletin, Rome., 19, 36 37.

27. Nawrot, T., Plusquin, M. and Hogervorst, J. (2006) Environmental exposure to cadmium and risk of cancer: a prospective population-based study. Lancet Oncol., 7(2): 119-126.

28. Nor, W. A. Z. N., Syakirah, A. M., Saffaatul, H. I. and Wan, A. A. W. A. (2012) Assessment of Heavy Metals in Soil due to Human Activities in Kangar, Perlis, Malaysia. International Journal of Civil \& Environmental Engineering, 12(6): 28-33.

29. Nwachukwu, H. A., Feng, H. and Alinnor J (2010) Assessment of heary metal pollution in soil and their implications within and around mechanic villages. Int. J. Environ. Sci. Tech, 7 (2): 347-358.

30. Odoh, R., Agbaji, E. B., and Kagbu, J. A. (2011). Assessment of Trace Metals Pollution in Auto-Mechanic Workshop in Some Selected Local Government Area of Benue State, Nigeria International Journal of Chemistry. International Journal of Chemistry,3(4): 78-88.

31. Ojiako, E. N and Okonkwo, M. N (2013) Analysis of heavy metals in soil of mechanic workshop in Onitsha metropolis. Advances in Applied Science Research, 4(1): 79-81.

32. Okeke, C. U., Ekanem, E. O., Harami, A. M. (2014) Bioaccumulation of Heavy Metals in Mechanic Workshops. International Journal of Mathematics and Physical Sciences Research, 2 (1): 58-65.

33. Ololade, I. A. (2014) An Assessment of Heavy-Metal Contamination in Soils within Auto-Mechanic Workshops Using Enrichment and Contamination Factors with Geoaccumulation Index. Journal of Environmental Protection,5: 970-982.

34. Omran, E. S. and El Razek, A. (2012) Mapping and risk assessment of Heavy Metals concentrations of the Bahr El - Baker Region, Egypt. J. Soil Environ. Manag., 6 (7): 182 - 195

35. Onweremadu, E. U. and Duruigbo, C. E. (2007) Assessment of Cd concentration of crude oil polluted arable soil. International Jorunal of Environmental Science Technology, 4 (3): 409 - 412.

36. Osakwe, S. A. (2014) Heavy metal contamination and physicochemical characteristics of soils from automobile workshops in Abraka, Delta State, Nigeria. International Journal of Natural Sciences Research, 2(4): 48-58.

37. Parven, N., Bashar, M. A. and Quraishi, S. B. (2009) Bioaccumulation of Heavy and Essential Metals in Trophic levels of Pond Ecosystem. Journal of Bangladesh Academy of Science, 33 (1), 131-137.

38. Saroj, M. and Dilip, B. (2014) Assessment of Physico-Chemical characteristics of the Soil of Nagchoon Pond Khandwa, MP, India. Research Journal of Chemical Sciences., 4(1): 26-30.

39. Seifi, M. R., Alimardani, R. and Sharifi, A. (2010) How Can Soil Electrical Conductivity Measurements Control Soil Pollution? Research Journal of Environmental and Earth Sciences, 2(4): 235 - 238

40. Triantafilis, J., Ahmed, M. F. and Odeh, I. O. A. (2002) Application of a mobile electromagnetic sensing system (MESS) to assess cause and management of soil salinization in an irrigated cotton-growing field. Soil Use Manage., 18(4): 330-339.

41. Victor B. A. (2009) Heavy metals in the environment and their health effects: In Wide Life Animal (http://wild-life-animal.blogspot.co.ke/2009/07/heavy-metals-and-their-html?m=1). Assessed September 6th, 2017. 